\title{
Towards an understanding of the success factors in international twinning and sister-city relationships
}

\author{
J.C. de Villiers*, T.J. de Coning and E.v.d.M. Smit \\ Graduate School of Business, University of Stellenbosch \\ PO Box 610, Bellville 7535, Republic of South Africa \\ kosie@stellenbosch.co.za
}

Received December 2006

\begin{abstract}
The twinning of cities has evolved from an international instrument of friendship and cultural exchange to a powerful tool for capacity building and economic development. Within this context it can be defined as a 'long-term strategic alliance between communities in different cities or towns, in which their municipalities are key actors'. There exists, however, a paucity of research about the twinning phenomenon and its success factors. In order to understand more fully which factors contribute to success, success factors reported in the available literature were identified, and a number of hypotheses formulated. These were then empirically tested from a survey conducted amongst all the municipalities of South Africa.
\end{abstract}

*To whom all correspondence should be addressed.

\section{Introduction}

The international links of local communities worldwide have moved from the simple twinning of cities to more complex webs of relationships including multiple linkages and networks of relationships. But twinning still remains a core means of establishing and maintaining relationships between local communities and municipalities across international borders.

The concept of the international twinning of cities and towns can be traced back to 1920 but the first twinning after the end of World War Two was between Bristol in the United Kingdom and Hanover in Germany in 1947, followed by twinnings between Oxford and Bonn, and Reading and Düsseldorf (Weyreter, 2003: 37). These twinnings were aimed at reaching out to German cities destroyed by the war. This was followed in 1956 by an organised twinning programme in America, initiated by President Eisenhower as an outgrowth of his People-to-People programme, which later evolved into Sister Cities International (SCI). These twinning initiatives in both Europe and America focused on interaction between citizens and communities at the local level across international borders.

It is estimated that between 15,000 and 20,000 towns and cities across the globe are currently twinned through various forms of partnering agreements (UNDP, 2000: 3), and different terms are used to describe a long-term partnership between two communities: sister cities, twin cities, friendship cities, partnerstadt (in Germany) and jumelage (in France) (SCI, 2003: 2). Related terms currently used in Europe are decentralised cooperation, municipal international cooperation, city-to-city cooperation (C2C), and stedenbanden (in the Netherlands). This type of diplomatic activity is also called paradiplomacy or low diplomacy. There is no consensus on an exact definition of twinning but De Villiers (2005: 20) proposes, based on an evaluation of current definitions, that a city or town twinning be defined as: 'a long-term strategic alliance between communities in different cities or towns, in which their municipalities are key actors'. A community is defined as (De Villiers, 2005: 14): 'The citizens (who may be characterised by similar or different cultures, values and languages), local government administration, civil society groups and business organisations, which together comprise a sub-national geographic entity'.

During the 1980s the nature and goals of twinning changed. Whereas relationships were formed initially between Northern cities and towns in Europe and the USA, NorthEast relationships were now also formed between these Northern cities and the Soviet Union and Eastern Europe. At the same time twinning also evolved as a means of outreach to Third World countries, called North-South twinnings (Zelinsky, 1991). Over the past fifty years, there have been significant changes in the nature of these relations. SCI (2002), for instance, identified the following trends that are driving the formation of international relationships at the local level:

- Increased democratisation and decentralisation globally;

- Privatisation, the growth of the non-governmental (NGO) or private voluntary (PVO) sector, and unique public/private partnerships;

- The revolution in communications and reduced travel time; and

- The effects of globalisation. 
Decentralisation of powers to local government forces this sphere of government to become more entrepreneurial in achieving local economic development. In addition, the trend to address development issues at the local level through the medium of twinning has also become a key strategy of the international development community to achieve the aims of Local Agenda 21 and to reach the Millennium Development Goals.

The concept of twinning is also not static and has evolved significantly since its origin. O’Toole (2001: 405) has identified different stages in the development of twinning in Australia, where the emphasis has changed from friendship ties, to exchange, to economic development. Older definitions thus focus more on the friendship aspects whereas later definitions make provision for economic development and focus more on developmental aspects. These three different but interlinking and overlapping approaches (phases) are:

1. Associative phase (twinning based on friendship, cultural exchange);

2. Reciprocative phase (twinning based on educational exchange, people exchange); and

3. Commercial exchange phase (twinning based on economic development).

It can be argued that in a time of globalisation, twinning is becoming increasingly important. The United Nations observes that there is a disparity in modern politics. 'Economics, trade, communications and even culture are becoming more global. But representative democracy remains essentially national and local. Since more decisions are being reached in international forums and organisations, it is becoming more important to develop a stronger framework for global governance with democratic accountability to citizens everywhere' (UN, 2004: 24).

\section{Types of relationships}

Researchers in the field of twinning have identified the severe paucity of research that exists about this phenomenon (Zelinski, 1991; De Villiers, 2005). In addition, no attempt has been made to analyse the phenomenon of twinning with a holistic systematic approach. De Villiers (2005) explores the twinning phenomenon on the macro (international), meso (national), and micro (local) levels. He also analyses twinning in terms of it context, content and structure. As part of this systemic look at twinning, three different but closely related types of international relationships at the local level are defined: Municipal International Cooperation, which constitutes a twinning of municipalities; Sister Cities or City Twinning, which constitutes twinning relations between communities; and Decentralised Cooperation, which constitutes using a municipal or community twinning for the purpose of channelling development cooperation funding. These three variations of twinning are described in more detail below.

\section{Municipal international cooperation}

Municipal International Cooperation (MIC) is a name for the international relations of municipalities. This could be in the form of a short- or long-term agreement between two or more municipalities, or could even refer to membership of an international network of municipalities. The programmes and activities promoted by bodies like United Cities and Local Government (UCLG), for instance, fall in this category. The aim is normally focused on technical cooperation which constitutes capacity-building initiatives between Northern and Southern municipalities or municipalities working together on a certain theme or initiative (e.g. Local Agenda 21). These municipal-tomunicipal diplomatic relations are sometimes also called city-to-city cooperation (C2C), although this term is also used by some to refer to community twinnings, as discussed in the next section.

\section{Sister cities and city twinning}

In the concept of a sister city or a twinning of communities, 'town' and 'city' refer not only to the local government or municipality, but the whole community, including civil society, the business community, and the education sector. The local government plays a very important facilitating role in setting up and maintaining the relationship, but the primary bond is forged between communities and not only between local governments. 'Sister-city programs are unique in that they inherently involve the three main sectors in a community: local government, businesses, and a wide variety of citizen volunteers' (SCI, 2003: 2). This relationship form can also be seen as organised or facilitated citizen-to-citizen diplomacy.

\section{Decentralised cooperation}

The concept of Decentralised Cooperation (DC) was first embodied in the European Union's Lomé Convention in 1990 and 'embraces a wider range of actions for development carried out by non-state actors, locally based institutions and voluntary associations of all kinds' (UNHabitat, 2001: 4). Hafteck (2003: 336) observes that DC comes from a fusion of the quest for donors to find alternative aid delivery channels, and a drive for local government associations and their members to diversify their collaborative relationships with foreign partners. He suggests that the concept be defined in terms of (a) local governments as the lead actors, (b) the objective being sustainable local development, and (c) the activities comprising exchanges and support. This relationship form mostly utilise North/South twinnings and in short, can be seen as linking or twinning for development.

It is clear that the concepts of municipal international cooperation, twinning, and decentralised cooperation are very closely related and a relationship could transform from one into another. Should a donor, for instance, discontinue its funding in a DC arrangement, the twinning might continue, reverting back to a pure municipal cooperation or community twinning relationship. 


\section{Success factors}

Twinning relationships exist at the local level and the questions: which relations are successful, and what factors contribute to success, can be asked. These questions give rise to a number of further questions, such as how should success be defined and how should it be measured.

Success factors for twinning identified by Sister Cities International, the United Nations Development Programme, the New Zealand Institute of Economic Research, the City of Bonn, and various research studies are listed below (De Villiers, 2005):

- $\quad$ Alliance capability - having the knowledge and skills to twin successfully.

- Concentrating resources by limiting the number of partners, and choosing partners carefully that can assist the community in reaching its specific goals.

- A contract or memorandum of understanding having been signed, thereby formalising the relationship. This agreement should have a long-term focus.

- Clear objectives, goals and planned activities summarised in a strategic plan or business plan.

- Solid support from the municipal council and the commitment of its management.

- $\quad$ Broad-based community involvement - sub-alliances between as many institutions, groups and organisations as possible, including solid support from the business sector.

- Capacity to manage the relationship in the form of budget and dedicated staff. Normally a broad-based twinning committee from each partner is also required.

- $\quad$ Reliable and regular communications.

- Regular exchanges.

- Strong relationship formation that tie the two communities together. The foundation of this relationship is built on certain attitudes. These are: trust, reciprocity, commitment, understanding, cultural sensitivity, attitude towards risk, and flexibility.

- Regular evaluation and revision of the agreement and relationship.

- An enabling policy and institutional environment to facilitate successful twinning.

An analysis of the way in which the above success factors were identified revealed that most sources were led to their conclusions by limited case study analyses, and no attempts were made to define what twinning success is, or to establish twinning success factors through quantitative research.

\section{Primary research}

In order to test whether the success factors found in the literature could be substantiated through empirical quantitative research, primary survey research was conducted amongst the 284 municipalities of South Africa. Although local-level twinning and municipal international relations are relatively new in South Africa, having grown from only seven relationships in 1988 (Zelinsky, 1991: 12), these developments took place in a rapidly evolving political and legal environment within South Africa, strongly influenced by the context of a new democratic government, and a rapidly changing global world (De Villiers, 2005).

Based on the reported success factors listed in the previous section, a number of hypotheses were generated in order to explore what the characteristics of successful twinning relationships were. These hypotheses are as follows:

Firstly, two hypotheses concerning the municipality or community as a twinning entity:

Hypothesis 1: Communities that have a twinning strategy in place have more alliance success.

Hypothesis 2: Communities with more alliance experience have more alliance success.

Secondly, a number of further hypotheses concerning the twinning relationships themselves:

Hypothesis 3: Twinnings where positive attitudes (including trust, commitment and reciprocity) are high have more alliance success.

Hypothesis 4: Twinnings where community involvement is high have more alliance success.

Hypothesis 5: Twinnings with higher levels of contact (exchange and communication) have more alliance success.

Hypothesis 6: Twinnings with more resources and infrastructure have more alliance success.

Hypothesis 7: Twinnings that followed a structured planning process (from partner selection to business planning) have more alliance success.

Hypothesis 8: Twinnings where leadership and management are strong have more alliance success.

Hypothesis 9: Twinnings that do active marketing have more alliance success.

Hypothesis 10: Twinnings where the partners have similar characteristics have more alliance success. 
These hypotheses were operationalised in terms of specific constructs that were included as scale items in the questionnaire. In order to test the hypotheses a construct 'alliance success,' had to be developed first. Success was defined as 'the degree to which the twinning achieved its original objectives as set out in the twinning agreement'. Two questions were included in the questionnaire to measure the success of the relationship: firstly, the question on the perceived success against the original objectives, and secondly, what the state of the relationship was currently.

For all of the hypotheses, a number of further constructs had to be operationalised and question items developed to measure these. Listed in Table 1 are these constructs and the measures that were developed and included in the questionnaire. The total population of South Africa's 284 municipalities was included in the study (including six metropolitan municipalities, 47 district municipalities, and 231 local municipalities). In the questionnaire, twinning was defined as 'formal relationships between your municipality/community or a part thereof, and international partner districts/cities/towns'. It therefore included all three the variations of international relations discussed previously.

Of the 53 municipalities that were found to have current international relationships, 28 completed usable questionnaires to assess issues about the municipality $(52,8$ per cent of these municipalities) and 26 of these 28 could be used to assess 37 of their international relationships (28,5 per cent of current international relationships).

A total of 171 international relationships in various stages of formation were reported. Of the ones already established, over half (51,7 per cent) were established with just four countries (China, the Netherlands, the United Kingdom and the United States of America). Three municipalities (Buffalo City, Cape Town and Johannesburg) together were responsible for over half $(50,4 \%)$ of all these relationships.

When the municipalities were asked for the most important success factors, they replied as follows in order of importance (De Villiers, 2005: 305):

1. Must have local economic development benefits (e.g. must offer investment, tourism growth and/or trade opportunities);

2. There must be socio-economic interaction, including citizen and business involvement;

3. Promotion of cultural ties and exchange;

4. Must fit into council's integrated development plan (IDP);

5. Must result in concrete projects and programmes, action plans and targets;

6. Dedicated staff in both municipalities and good coordination;

7. There must be knowledge sharing/education;
8. Must choose districts with similar characteristics;

9. The needs of the relationship must be identified and activities must be based on actual needs;

10. Be beneficial to both parties and their respective communities;

11. Mutual goals (agreement on areas of cooperation);

12. Must offer exchange programmes;

13. Must promote health (AIDS and STD awareness);

14. Must promote academic exchange/cooperation; and

15. There must be political will and commitment and local municipal buy-in/support.

Although municipalities listed these perceived success factors, few of them could report applying some or all of these factors to increase twinning success.

Citizens were, for instance, involved in less than half of the relationships and only 53,6\% of municipalities had a written linking or twinning strategy in place. Of these, only a third had fully developed visions, goals and criteria for partner selection. In only $26,7 \%$ of cases was the linking or twinning strategy fully integrated with the municipality's IDP (De Villiers, 2005: 302). Municipalities also did not have the best calibre of management to manage the twinning (only 26\% had), very little marketing of the twinning took place (only in $18 \%$ of cases), and only $29,7 \%$ of cases had a written business plan that spelt out concrete programmes and activities (De Villiers, 2005: 313).

\section{Hypothesis testing}

In order to ascertain which variables possibly influence the success of twinnings, the hypotheses that were derived from the literature on alliances and twinning were tested with the data from the present study. The questionnaire listed two questions concerning the success of each relationship. The first was about the perceived success of the relationship when compared to the initial objectives, which respondents were asked to rate on a 7-point interval scale. The second measure of success of the twinning relationship was a question about the state of the relationship. These responses were classified and coded into the following three categories on an ordinal scale: Negative, Neutral and Positive.

These two measures were then combined into a composite measure of success called 'alliance success'. In order to do so, the reliability of the scores were checked by calculating Cronbach Alpha to estimate the proportion of true score variance that is captured by the items by comparing the sum of item variances with the variance of the sum scale. In this case Alpha was 0,780, which indicated an acceptable level of reliability (Nunnally \& Bernstein, 1994). The Spearman rank order correlation that was calculated also measured a significant correlation of $0,697(p<0,01)$ between the two measures. 
Table 1: Constructs and measures

\begin{tabular}{|c|c|c|}
\hline Hypotheses & Constructs & Measures \\
\hline 1 & $\begin{array}{l}\text { Twinning } \\
\text { strategy }\end{array}$ & $\begin{array}{ll}- & \text { Existence of twinning } \\
\text { strategy }\end{array}$ \\
\hline 2 & $\begin{array}{l}\text { Alliance } \\
\text { experience }\end{array}$ & $\begin{array}{ll}\text { - } & \text { Stability of political } \\
\text { leadership (years council in } \\
\text { office) } \\
\text { - } & \text { Number of twinnings } \\
\text { - } & \text { Number of years since first } \\
\text { twinning }\end{array}$ \\
\hline 3 & $\begin{array}{l}\text { Positive } \\
\text { attitudes }\end{array}$ & $\begin{array}{ll}\text { - } & \text { Trust } \\
\text { - } & \text { Reciprocity } \\
\text { - } & \text { Commitment } \\
\text { - } & \text { Understanding } \\
\text { - } & \text { Cultural sensitivity } \\
\text { - } & \text { Risk } \\
\text { - } & \text { Flexibility }\end{array}$ \\
\hline 4 & $\begin{array}{l}\text { Community } \\
\text { involvement }\end{array}$ & $\begin{array}{l}\text { - } \text { Twinning type (whether } \\
\text { community is involved) } \\
\text { - } \quad \text { Community actors involved } \\
\text { - Community awareness of the } \\
\text { twinning }\end{array}$ \\
\hline 5 & $\begin{array}{l}\text { Intensity of } \\
\text { communication }\end{array}$ & $\begin{array}{ll}\text { - } & \text { Actors involved in } \\
\text { communication } \\
\text { - } & \text { Frequency of communication }\end{array}$ \\
\hline 6 & $\begin{array}{l}\text { Resources and } \\
\text { infrastructure }\end{array}$ & $\begin{array}{ll}\text { - } & \text { Budget } \\
\text { - } & \text { Donor-funded or not } \\
\text { - } & \text { Structural arrangements }\end{array}$ \\
\hline 7 & $\begin{array}{l}\text { Structured } \\
\text { planning } \\
\text { process }\end{array}$ & 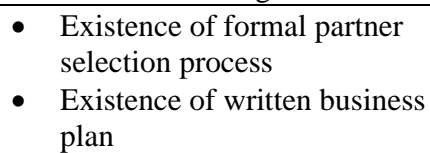 \\
\hline 8 & $\begin{array}{l}\text { Leadership and } \\
\text { management }\end{array}$ & $\begin{array}{l}\text { Professional management } \\
\text { available } \\
\text { Involvement of twinning } \\
\text { champion }\end{array}$ \\
\hline 9 & $\begin{array}{l}\text { Active } \\
\text { marketing }\end{array}$ & $\begin{array}{ll} & \text { Marketing taking place } \\
\text { - } & \text { Level of media exposure of } \\
\text { twinning }\end{array}$ \\
\hline 10 & $\begin{array}{l}\text { Partner } \\
\text { similarity }\end{array}$ & $\begin{array}{ll}\text { - } & \text { Languages spoken } \\
\text { - } & \text { Religion (s) } \\
\text { - } & \text { Geographic terrain } \\
\text { - } & \text { Historical background } \\
\text { - } & \text { Places/facilities/amenities } \\
\text { - } & \text { Educational facilities } \\
\text { - } & \text { Organisations, associations } \\
\text { - } & \text { Key industries } \\
\text { - } & \text { Commer country culture } \\
\text { - } & \text { Goals for twinning } \\
\text { - } & \text { Expectations of outcomes } \\
\text { - } & \text { Commitment of management } \\
\text { - } & \text { Strengths and weaknesses } \\
\text { - } & \text { Personalities involved }\end{array}$ \\
\hline
\end{tabular}

Source: De Villiers, 2005: 271.
The two measures were therefore normalised and combined with equal weighting into one new measure of success called 'alliance success'. The hypotheses were then tested and a significance level of 5 per cent was used in all tests. Hypothesis testing involved either correlation testing, or analysis of variance testing (ANOVA), to test for significant differences between means. It was assumed that the dependent variable is measured on at least an interval scale (Statistica, 2004).

\section{Hypothesis 1: Twinning strategy and alliance success}

In this test the variable 'twinning strategy' which simply indicates whether a municipality has a twinning strategy or not (measured on a nominal scale) is examined, to ascertain whether there is a significant difference in the success of the two groups (success being measured on an interval scale).

Analysis of variance (ANOVA) was used for this test at a significance level of 5 per cent $(p=<0,05)$. The observed value of the test statistic $(F)$ was $F=0,611$ and the value of $p$ was $p=0,441$. As the $p$ level is greater than 0,05 , the null hypothesis cannot be rejected. It is thus evident that the hypothesis that the existence of a twinning strategy by a municipality or community leads to more alliance success cannot be proven.

\section{Hypothesis 2: Alliance experience and alliance success}

In this test the construct 'alliance experience' is proposed to consist of three components, which are all individually correlated against 'alliance success'. These components, which were all measured separately in the questionnaire, are:

1. The length of time in years that the current council is in office, i.e. the stability of political leadership (it is assumed that the longer the council is in office, the more experience they would have with alliances);

2. The number of twinnings (it is assumed that the more twinnings the municipality has, the more experience it would have with alliances); and

3. The number of years that the municipality has been involved in twinning, measured by a question about the year of first twinning (it is assumed that the longer a municipality has been involved in twinnings, the more experience it would have).

These correlations are listed in Table 2. According to these results, no significant correlation could be found between any of these three component variables of 'alliance experience' and the success of twinning.

\section{Hypothesis 3: Positive attitude and alliance success}

It is evident from success factors identified earlier that certain attitudes of alliance partners can influence the success of the relationship. It was therefore postulated that 
twinnings where positive attitudes are high have more alliance success. The attitudes that were found to be important in the literature on alliances are: trust, reciprocity, commitment, understanding, cultural sensitivity, attitude towards risk, and flexibility.

Two series of questions in the questionnaire probed the attitudes displayed in the relationship, firstly of the respondent (self), and secondly the perception of the partner attitude (partner). These attitudes, measured on a 5-point Likert Scale, are listed in Table 3. Not all attitudinal measures can be positively linked to the success of alliances. Of the measures, the following showed significant correlations with alliance success at the 5 per cent significance level:

- $\quad$ Commitment (of the partner);

- $\quad$ Understanding (by yourself);

- $\quad$ Understanding (by the partner); and

- Cultural sensitivity (of the partner).

Table 2: Alliance experience and alliance success

\begin{tabular}{l|c|c|c|c}
\hline \multicolumn{5}{c}{$\begin{array}{c}\text { Spearman Rank Order Correlations Marked correlations are } \\
\text { significant at p }<.05000\end{array}$} \\
\hline & Valid n & Spearman & t(N-2) & p-level \\
\hline $\begin{array}{l}\text { Success \& Length } \\
\text { (years) }\end{array}$ & 29 & 0,030 & 0,157 & 0,876 \\
\hline Success \& Number & 30 & 0,019 & 0,099 & 0,922 \\
\hline $\begin{array}{l}\text { Success \& Year of } \\
\text { first twin }\end{array}$ & 28 & 0,042 & 0,217 & 0,830 \\
\hline
\end{tabular}

Table 3: Positive attitude and alliance success (individual scores)

\begin{tabular}{l|c|c|c|c}
\hline \multicolumn{5}{c}{$\begin{array}{c}\text { Spearman Rank Order Correlations Marked correlations are } \\
\text { significant at p } \mathbf{4 . 0 5 0 0 0}\end{array}$} \\
\hline & $\begin{array}{c}\text { Valid } \\
\text { n }\end{array}$ & Spearman & $\begin{array}{c}\mathbf{t}(\mathbf{N}- \\
\mathbf{2} \text { ) }\end{array}$ & $\begin{array}{c}\mathbf{p}- \\
\text { level }\end{array}$ \\
\hline Success \& Trust (self) & 28 & 0,231 & 1,211 & 0,237 \\
\hline Success \& Trust (partner) & 27 & 0,360 & 1,934 & 0,065 \\
\hline $\begin{array}{l}\text { Success \& Commitment } \\
\text { (self) }\end{array}$ & 29 & 0,164 & 0,865 & 0,394 \\
\hline $\begin{array}{l}\text { Success \& Commitment } \\
\text { (partner) }\end{array}$ & 28 & $\mathbf{0 , 5 5 1}$ & 3,366 & $\mathbf{0 , 0 0 2}$ \\
\hline $\begin{array}{l}\text { Success \& Reciprocity } \\
\text { (self) }\end{array}$ & 27 & 0,158 & 0,799 & 0,432 \\
\hline $\begin{array}{l}\text { Success \& Reciprocity } \\
\text { (partner) }\end{array}$ & 26 & 0,251 & 1,271 & 0,216 \\
\hline $\begin{array}{l}\text { Success \& Understanding } \\
\text { (self) }\end{array}$ & 28 & $\mathbf{0 , 4 5 9}$ & 2,636 & $\mathbf{0 , 0 1 4}$ \\
\hline $\begin{array}{l}\text { Success \& Understanding } \\
\text { (partner) }\end{array}$ & 27 & $\mathbf{0 , 4 7 6}$ & 2,707 & $\mathbf{0 , 0 1 2}$ \\
\hline $\begin{array}{l}\text { Success \& Cultural } \\
\text { sensitivity (self) }\end{array}$ & 27 & 0,204 & 1,040 & 0,308 \\
\hline $\begin{array}{l}\text { Success \& Cultural } \\
\text { sensitivity (partner) }\end{array}$ & 27 & $\mathbf{0 , 3 9 1}$ & 2,121 & $\mathbf{0 , 0 4 4}$ \\
\hline Success \& Risk (self) & 28 & 0,368 & 2,020 & 0,054 \\
\hline Success \& Risk (partner) & 27 & 0,277 & 1,441 & 0,162 \\
\hline Success \& Flexibility (self) & 26 & 0,264 & 1,342 & 0,192 \\
\hline $\begin{array}{l}\text { Success \& Flexibility } \\
\text { (partner) }\end{array}$ & 27 & 0,280 & 1,454 & 0,158 \\
\hline
\end{tabular}

It was also investigated whether one combined measure for 'positive attitude' of both the respondent (self) and the partner could be compared to alliance success. In order to test the reliability of the different measures for self and partner, Cronbach Alpha was used. For the measures for own attitudes a strong Alpha of 0,939 was obtained, with the combination of partner attitudes delivering an equally strong score of 0.921 . It was therefore decided to combine the individual attitudes into a single measure of attitude for self and partner.

In Table 4, the attitudes for self and partner are combined and correlated with alliance success. Although the correlation for overall attitude of self was not significant, the overall attitude of the partner is significantly correlated with alliance success on the 5 per cent significance level.

\section{Table 4: Positive attitude and alliance success}

\begin{tabular}{l|c|c|c|c}
\hline \multicolumn{5}{c}{$\begin{array}{c}\text { Spearman Rank Order Correlations Marked correlations are } \\
\text { significant at p }<.05000\end{array}$} \\
\hline & Valid n & Spearman & t(N-2) & p-level \\
\hline $\begin{array}{l}\text { Success \& Attitude } \\
\text { (self) }\end{array}$ & 24 & 0,273 & 1,330 & 0,197 \\
\hline $\begin{array}{l}\text { Success \& Attitude } \\
\text { (partner) }\end{array}$ & 26 & $\mathbf{0 , 4 3 7}$ & 2,378 & $\mathbf{0 , 0 2 6}$ \\
\hline
\end{tabular}

\section{Hypothesis 4: Community involvement and alliance success}

In the literature, the importance of community involvement is stressed by numerous sources as an important factor in the success of alliances. Various measures of community involvement were therefore built into the questionnaire and tested in this section. These were measures of:

1. Twinning type (whether community is involved or not). One question asked for the role players involved in the twinning and this was coded as a simple yes/no response for community (individuals, NGOs and business);

2. Community awareness of the twinning (it is postulated that the more people in the community as a percentage of the total know about the twinning, the more successful it should be); and

3. Number of actors involved (it is postulated that the more actors are involved in the twinning, the more successful it should be).

Firstly, it was postulated that alliance success would be higher in twinnings where community involvement is high. Analysis of variance (ANOVA) was used for this test at a significance level of 5 per cent $(p=<0,05)$. The observed value of the test statistic $(F)$ was $F=0,341$ and the value of $\mathrm{p}$ was $\mathrm{p}=0,564$. As the $\mathrm{p}$ level is greater than 0,05 , the null hypothesis cannot be rejected. No significant correlation on the 5 per cent significance level could therefore be found to support the hypothesis that twinnings are more successful where community involvement is high. In Table 5 it is also evident that the number of actors involved in the twinning 
does not provide a significant correlation on the 5 per cent significance level with alliance success, and therefore no conclusion can be made about the role of this variable. Awareness of the twinning, however, was positively correlated to alliance success on the 5 per cent significance level.

\section{Hypothesis 5: Communication and alliance success}

It was suggested earlier that frequent communication by a large variety of actors is necessary for alliance success, as alliances are formed and maintained also at the personal level. It is therefore logical to assume that the more actors are involved in a twinning, and the more frequently they communicate, the more successful the relationship would be. The two variables that are used for the test are:

- Actors involved in communication; and

- $\quad$ Frequency of communication.

These two variables were therefore investigated, and the actors involved were also broken down into groups in order to ascertain whether specific groups are more important for alliance success. These results are presented in Table 6.

Although no significant positive relationships were found at the 5 per cent significance level between any of the actors and alliance success, a significant negative relationship was found between the communication of officials and alliance success. In the twinnings where officials communicated more, twinnings were less successful.

\section{Hypothesis 6: Resources and infrastructure and alliance success}

The literature also pointed to the fact that twinnings with more resources in terms of human resources, funding and infrastructure have more alliance success. Three variables to measure this construct of resources and infrastructure were therefore chosen as follows:

- $\quad$ Donor-funded or not (yes/no dichotomous question);

- $\quad$ Budget (annually committed to the twinning in South African Rand); and

- Structural arrangements (whether the municipality had a permanent function for twinnings, a part-time function, or no function at all).

Analysis of variance (ANOVA) was used to test the relationship between donor funding and alliance success. The observed value of the test statistic $(F)$ was $F=0,288$ and the value of $p$ was $p=0,596$. As the $p$ level is greater than 0,05 , the null hypothesis cannot be rejected. As far as donor funding is concerned, the results indicate that it cannot be proven that there is a significant relationship between donor funding and alliance success.

In Table 7, the relationship between alliance success and the other two variables is investigated. The type of structural commitment at the municipality did not seem to make a significant difference to alliance success but the budget allocation might. Although budget amount is not significantly correlated to alliance success on the 5 per cent significance level, it is on the 10 per cent significance level.

\section{Hypothesis 7: Structured planning process and alliance success}

It is postulated here that twinnings that followed a structured planning process (from partner selection to business planning and formalised in a written agreement) have more alliance success. As most cases had written agreements, this variable was not included in the test. The planning process therefore consisted of two variables:

- $\quad$ The existence of a formal partner selection process (on a 3-point ordinal scale); and

- $\quad$ Existence of written business plan (yes/no dichotomy).

Firstly, the test in Table 8 was conducted to ascertain whether there was a significant correlation between having such a process and alliance success. The results show that although there is no significant relationship on the 5 per cent level, there is a trend, as a relationship exists bordering on the 10 per cent significance level.

Analysis of variance (ANOVA) was used to test the relationship between the existence of a business plan and alliance success. The observed value of the test statistic (F) was $F=5,597$ and the value of $p$ was $p=0,025$. As the $p$ level is smaller than 0,05 , the null hypothesis can be rejected. There was a significant difference in alliance success between the two groups, those who had a business plan and those who had not. The existence of a business plan therefore can be seen to influence alliance success positively.

\section{Hypothesis 8: Leadership and management and alliance success}

It is also implied in the success factors listed that leadership and quality of management are important in achieving alliance success. The variables used to test this construct are listed below:

- $\quad$ Professional management available (question on 3-point scale);

- Management commitment on both sides (question on 3point scale);

- Involvement of twinning champion (yes/no dichotomy); and

- $\quad$ Complexity of management structure (e.g. No structure, Loose association (without formal structure), Sister-city association, City commission (appointed by mayor), Corporation (separate legal entity)).

As is evident from Table 9, there exists a significant positive relationship on the 5 per cent significance level between 
quality of management and alliance success, and between management commitment and alliance success. Although the relationship between a dedicated structure for the twinning and alliance success is not significant on a 5 per cent level, there is a trend, as such a significant relationship exists on the 10 per cent significance level.

Table 5: Community awareness, number of actors and alliance success

\begin{tabular}{l|c|c|c|c}
\hline \multicolumn{5}{c}{$\begin{array}{c}\text { Spearman Rank Order Correlations Marked correlations are } \\
\text { significant at p }<.05000\end{array}$} \\
\hline & Valid n & Spearman & T(N-2) & p-level \\
\hline Success \& Awareness & 24 & $\mathbf{0 , 5 1 1}$ & 2,790 & $\mathbf{0 , 0 1 1}$ \\
\hline $\begin{array}{l}\text { Success \& Number of } \\
\text { Actors }\end{array}$ & 29 & 0,138 & 0,722 & 0,476 \\
\hline
\end{tabular}

Table 6: Frequency of contact and alliance success

\begin{tabular}{l|c|c|c|c}
\hline \multicolumn{5}{c}{$\begin{array}{c}\text { Spearman Rank Order Correlations Marked correlations are } \\
\text { significant at p }\end{array}$} \\
\hline & $\begin{array}{c}\text { Valid } \\
\text { n }\end{array}$ & Spearman & $\mathbf{t ( N - 2 )}$ & $\begin{array}{c}\mathbf{p}- \\
\text { level }\end{array}$ \\
\hline $\begin{array}{l}\text { Contact (Businesses) \& } \\
\text { Success }\end{array}$ & 5 & $\mathbf{- 0 , 8 1 1}$ & $-2,402$ & 0,096 \\
\hline $\begin{array}{l}\text { Contact (NGOs and CS) } \\
\text { \& Success }\end{array}$ & 9 & 0,000 & 0,000 & 1,000 \\
\hline $\begin{array}{l}\text { Contact (Schools) \& } \\
\text { Success }\end{array}$ & 12 & 0,375 & 1,281 & 0,229 \\
\hline $\begin{array}{l}\text { Contact (Mayor) \& } \\
\text { Success }\end{array}$ & 24 & 0,220 & 1,056 & 0,302 \\
\hline $\begin{array}{l}\text { Contact (Officials) \& } \\
\text { Success }\end{array}$ & 12 & $\mathbf{- 0 , 6 7 0}$ & $-2,853$ & $\mathbf{0 , 0 1 7}$ \\
\hline
\end{tabular}

Table 7: Budget, structure and alliance success

\begin{tabular}{l|c|c|c|c}
\hline \multicolumn{5}{c}{$\begin{array}{c}\text { Spearman Rank Order Correlations Marked correlations are } \\
\text { significant at p } \mathbf{< . 0 5 0 0 0}\end{array}$} \\
\hline & Valid n & Spearman & $\begin{array}{c}\mathbf{t ( N -} \\
\mathbf{2})\end{array}$ & $\begin{array}{c}\mathbf{p}- \\
\text { level }\end{array}$ \\
\hline Success \& Budget (Rand) & 18 & 0,439 & 1,953 & 0,069 \\
\hline $\begin{array}{l}\text { Success \& Structure (at } \\
\text { municipality) }\end{array}$ & 30 & 0,280 & 1,542 & 0,134 \\
\hline
\end{tabular}

Table 8: Methodology and alliance success

\begin{tabular}{c|c|c|c|c}
\hline \multicolumn{6}{c}{$\begin{array}{c}\text { Spearman Rank Order Correlations Marked correlations are } \\
\text { significant at p <.05000 }\end{array}$} \\
\hline & Valid & Spearman & $\begin{array}{c}\mathbf{t}(\mathbf{N}- \\
\text { 2) }\end{array}$ & $\begin{array}{c}\text { p- } \\
\text { level }\end{array}$ \\
\hline Success \& Methodology & 29 & 0,310 & 1,696 & 0,101 \\
\hline
\end{tabular}

Table 9: Management, commitment, structure and alliance success

\begin{tabular}{l|c|c|c|c}
\hline \multicolumn{5}{c}{$\begin{array}{c}\text { Spearman Rank Order Correlations Marked correlations are } \\
\text { significant at p } \mathbf{0 . 0 5 0 0 0}\end{array}$} \\
\hline & $\begin{array}{c}\text { Valid } \\
\mathbf{n}\end{array}$ & Spearman & $\mathbf{t}(\mathbf{N}-\mathbf{2})$ & $\begin{array}{c}\mathbf{p}- \\
\text { level }\end{array}$ \\
\hline Success and Management & 30 & $\mathbf{0 , 6 4 5}$ & 4,463 & $<\mathbf{0 , 0 1}$ \\
\hline $\begin{array}{l}\text { Success \& Management } \\
\text { Commitment }\end{array}$ & 29 & $\mathbf{0 , 3 8 5}$ & 2,167 & $\mathbf{0 , 0 3 9}$ \\
\hline $\begin{array}{l}\text { Success \& Twinning } \\
\text { Structure }\end{array}$ & 29 & 0,354 & 1,969 & 0,059 \\
\hline
\end{tabular}

The involvement of a champion driving the twinning is reportedly also important for alliance success. Analysis of variance (ANOVA) was used to test the relationship between the involvement of a champion and alliance success. The observed value of the test statistic $(\mathrm{F})$ was $\mathrm{F}=$ 1,395 and the value of $p$ was $p=0,247$. As the $p$ level is greater than 0,05 , the null hypothesis cannot be rejected. From the test, it can be deduced that a positive relationship between the involvement of a champion and alliance success cannot be proven.

\section{Hypothesis 9: Marketing and alliance success}

The hypothesis that better marketing is associated more with successful alliances than unsuccessful ones was also investigated. This construct was measured in two ways:

- $\quad$ Marketing taking place (the level of marketing activity on a 3-point scale); and

- Level of media exposure of twinning (on a 3-point scale).

These two measures were combined into one measure for active marketing of the twinning. As the Cronbach Alpha for these two measures was very strong at 0,795 , this was deemed totally acceptable. In Table 10, the combined score is correlated with alliance success. From this result it is evident that there is a strong correlation of 0,638 between success and active marketing on the 5 per cent significance level.

\section{Hypothesis 10: Similarity and alliance success}

In the twinning literature it is suggested by various sources that similarity of twinning partners is important for success, but it was noted that in some cases, 'marriages of opposites' also work. It was therefore investigated whether similarity on a number of dimensions identified as important in selecting a twinning partner, correlates with alliance success.

Respondents were asked to rate how similar or different the two partners in the twinning were on the dimensions listed in Table 11. From this information it is evident that it cannot be proven conclusively from the data that similarity on most of the dimensions relates positively with alliance success. There were, however, a few individual dimensions that were exceptions. A significant positive correlation of 0,517 (p $<0,01$ ) was found between alliance success and management commitment. Another positive and significant correlation was found between the similarities of the personalities on both sides. Another correlation, although only significant on the 10 per cent level, was between the similarity of geographical terrain and success. What was interesting, though, was that a significant negative correlation was found between the key industries in the two areas, implying that in the twinnings that were successful, the key industries in the two communities were different. 
Table 10: Active marketing and alliance success

\begin{tabular}{l|c|c|c|c}
\hline \multicolumn{5}{c}{$\begin{array}{c}\text { Spearman Rank Order Correlations Marked correlations are } \\
\text { significant at p }<.05000\end{array}$} \\
\hline & Valid n & Spearman & $\mathbf{t}(\mathbf{N}-2)$ & p-level \\
\hline $\begin{array}{l}\text { Success and Active } \\
\text { Marketing }\end{array}$ & 29 & $\mathbf{0 , 6 3 8}$ & 4,311 & $<\mathbf{0 , 0 1}$ \\
\hline
\end{tabular}

Table 11: Similarity and alliance success

\begin{tabular}{l|c|c|c|c}
\hline \multicolumn{5}{c}{$\begin{array}{c}\text { Spearman Rank Order Correlations Marked correlations are } \\
\text { significant at p }<, 05000\end{array}$} \\
\hline & $\begin{array}{c}\text { Valid } \\
\text { n }\end{array}$ & Spearman & $\mathbf{t ( N - 2 )}$ & $\begin{array}{c}\mathbf{p}- \\
\text { level }\end{array}$ \\
\hline $\begin{array}{l}\text { Languages spoken \& } \\
\text { Success }\end{array}$ & 30 & 0,299 & 1,656 & 0,109 \\
\hline Religion (s) \& Success & 30 & 0,002 & 0,009 & 0,993 \\
\hline $\begin{array}{l}\text { Geographic terrain \& } \\
\text { Success }\end{array}$ & 29 & $-0,322$ & $-1,766$ & 0,089 \\
\hline $\begin{array}{l}\text { Historical background \& } \\
\text { Success }\end{array}$ & 28 & $-0,102$ & $-0,521$ & 0,606 \\
\hline $\begin{array}{l}\text { Places/facilities/amenities } \\
\text { \& Success }\end{array}$ & 30 & $-0,046$ & $-0,245$ & 0,808 \\
\hline $\begin{array}{l}\text { Educational facilities \& } \\
\text { Success }\end{array}$ & 30 & $-0,061$ & $-0,322$ & 0,749 \\
\hline $\begin{array}{l}\text { Organisations, associations } \\
\text { \& Success }\end{array}$ & 28 & $-0,210$ & $-1,093$ & 0,284 \\
\hline Key industries \& Success & 30 & $\mathbf{- 0 , 3 8 4}$ & $-2,199$ & $\mathbf{0 , 0 3 6}$ \\
\hline $\begin{array}{l}\text { Mother country culture \& } \\
\text { Success }\end{array}$ & 29 & 0,047 & 0,242 & 0,810 \\
\hline $\begin{array}{l}\text { Community value system } \\
\text { \& Success }\end{array}$ & 28 & 0,121 & 0,623 & 0,538 \\
\hline $\begin{array}{l}\text { Goals for twinning \& } \\
\text { Success }\end{array}$ & 30 & 0,231 & 1,255 & 0,220 \\
\hline $\begin{array}{l}\text { Expectations of outcomes } \\
\text { \& Success }\end{array}$ & 30 & 0,187 & 1,008 & 0,322 \\
\hline $\begin{array}{l}\text { Commitment of } \\
\text { management \& Success }\end{array}$ & 30 & $\mathbf{0 , 5 1 7}$ & 3,193 & $\mathbf{0 , 0 0 3}$ \\
\hline $\begin{array}{l}\text { Strengths and weaknesses } \\
\text { \& Success }\end{array}$ & 30 & 0,234 & 1,273 & 0,213 \\
\hline $\begin{array}{l}\text { Personalities involved \& } \\
\text { Success }\end{array}$ & 27 & $\mathbf{0 , 4 0 6}$ & 2,219 & $\mathbf{0 , 0 3 6}$ \\
\hline
\end{tabular}

\section{Conclusions and recommendations}

The last two decades of the twentieth century have been characterised by opposing forces of globalisation on the one hand, which leads to the centralisation of decision-making that manifests in global and regional organisations becoming more prominent in governance issues, and decentralisation on the other hand. The twinning phenomenon has not only grown tremendously since its inception but it has also changed significantly in character. It has evolved from its beginnings of focussing on citizen exchange and cultural and friendship ties to a powerful instrument for regional unity building, learning, and development. Its scope has therefore changed significantly. Besides the twinning between communities, other forms of international partnering at the local level have also evolved in the form of municipal international cooperation (MIC), which involves two or more municipalities and normally focuses on technical cooperation and capacity building, and decentralised cooperation (DC), which involves international aid and usually has a development-orientated focus. The field is, however, underresearched, and no real measurements are being conducted on the efficacy of twinnings, and in the literature no large-scale attempts have been made to establish whether the benefits of these relationships outweigh the costs.

This article therefore set out to identify the observed success factors of twinning and to validate them through empirical testing. The hypothesis that the existence of a twinning strategy by a municipality or community leads to more alliance success could not be proven. No significant correlation could be found between any of the three component parts of 'alliance experience' as defined in the research, and the success of twinning. Although not all attitudinal measures could be positively linked to the success of twinnings, partner commitment, understanding by both partners, and cultural sensitivity of the partner were important in successful relationships. All attitudes combined showed that, 'overall attitude' of the partner is significantly positively correlated with alliance success.

No significant correlation could be found to support the hypothesis that twinnings are more successful where community involvement is high. The number of actors involved in the twinning also did not provide a significant correlation with alliance success, and therefore no conclusion can be made about the role of this variable. Awareness of the twinning, however, is positively correlated with alliance success.

Although no significant positive relationships were found between the actors involved in the twinning and alliance success, a significant negative relationship was found between the communication of officials and alliance success. In the twinnings where officials communicated more, twinnings were less successful. This anomaly cannot be explained by the current data and further qualitative research into the twinnings responsible for this negative relationship will be necessary to find possible explanations.

As far as donor funding is concerned, it could not be proven that there is a significant relationship between donor funding and alliance success. But funding might be important for success, as although budget amount is not significantly correlated to alliance success on the 5 per cent significance level, it is on the 10 per cent significance level.

The importance of having a business plan for twinning success is confirmed by the study as there was a significant difference in alliance success between the two groups, those who had a business plan and those who had not.

The role of management is also very important and as expected, there exists a significant positive relationship between quality of management and alliance success, and between management commitment and alliance success. The relationship between the involvement of a champion and alliance success, however, could not be proven.

Another very strong correlation was found between alliance success and active marketing. A successful twinning involves the cooperation of many role-players on both sides of the relationship and it is expected that extensive communication would be necessary to obtain their support and active participation. 
As far as similarities in partners were concerned, a positive correlation was found between alliance success and management commitment and between the similarities of the personalities on both sides.

In summary, the success factors that were supported by the hypothesis testing thus are:

1. Partner commitment;

2. Understanding (self);

3. Partner understanding;

4. Cultural sensitivity (of partner).

5. Positive partner attitude;

6. Community awareness of the twinning;

7. Business plan;

8. Quality of management;

9. Management commitment;

10. Active marketing; and

11. Similarities of the personalities on both sides.

Twinning succeeds or fails at the local level and the findings of the primary research should be used as guidelines for the forging of twinning relationships. These include:

1. Proper partner selection is very important. The partners should be committed, show understanding and cultural sensitivity, and display an overall positive attitude. Similar personalities on both sides are also important;

2. Marketing to all stakeholders is very important to make everyone aware of the twinning, and to obtain their active participation;

3. As far as management is concerned, management quality and management commitment are very important success factors; and

4. Twinnings need to be supported by a well-conceived business plan spelling out objectives and plans for their achievement.

Although a number of key success factors identified in the literature such as having a twinning strategy and community involvement could not be empirically proven, further research is necessary to verify these results. This article reflects an exploratory attempt to identify the success factors for twinning, and although the research was conducted amongst South African communities, it can be used as a basis for further research in the global arena, as well as for practical application of the success factors to increase the probability of success in current twinning relationships.

\section{References}

Bucklin, P. \& Sengupta, S. 1993. 'Organising successful comarketing alliances’, Journal of Marketing, 57:32-46.

De Villiers, J.C. 2005. 'Strategic alliances between communities, with special emphasis on the twinning of South African cities and towns with international partners'. Unpublished doctoral dissertation, Graduate School of Business, University of Stellenbosch, Bellville Park Campus.
Hafteck, P. 2003. 'An introduction to decentralised cooperation: Definitions, origins and conceptual mapping', Public Administration and Development, 23: 333-345.

Nunnally, J.C. \& Bernstein, I.H. 1994. Psychometric theory. $3^{\text {rd }}$ Edition. New York: McGraw-Hill.

O’Toole, K. 2001. 'Kokusaika and internationalisation: Australian and Japanese sister city type relationships', Australian Journal of International Affairs, 55(3):403-419.

SCI (Sister Cities International). 2002. 'Sister Cities - at the cutting edge of economic and community development'. Washington. [Online] URL: http://www.sister-cities.org. Accessed 12 February 2002.

SCI (Sister Cities International). 2003. 'What are sister cities?' [Online] URL: www.sister-cities.org/sci/. Accessed 10 October 2003.

UN (United Nations). 2004. We the peoples: civil society, the United Nations and global governance - report of the panel of eminent persons on United Nations- civil society relations. General Assembly, Fifty-eighth session, Agenda item 59, Strengthening of the United Nations system. New York: UN.

UNDP (United Nations Development Programme). 2000. 'The challenges of linking'. Bureau for Development Policy. [Online] URL: http://magnet.undp.org/Docs/. Accessed 4 February 2002.

UN-Habitat. 2001. City-to-city cooperation: Issues arising from experience. IULA/UTO Unity Congress, Rio de Janeiro, 3-6 May 2001. United Towns Organisation (UTO/FMCU) on behalf of the World Associations of Cities and Local Authorities Coordination (WACLAC). Nairobi: United Nations Centre for Human Settlements (Habitat).

Weyreter, M. 2003. 'Germany and the town twinning movement', Contemporary Review, 281(1644): 37-43.

Zelinsky, W. 1991. 'The twinning of the world: Sister cities in geographic and historical perspective', Annals of the Association of American Geographers, 81(1): 1-31. 